\title{
FAKTOR YANG MEMENGARUHI EKSPRESI EMOSI ANAK DENGAN INDIKASI DISLEKSIA YANG MENJALANI TERAPI SENI EKSPRESIF
}

\author{
Joe Irene $^{1}$, Samsunuwiyati Mar'at ${ }^{2}$, Sri Tiatri $^{3}$ \\ ${ }^{1}$ Prodi Magister Psikologi Profesi, Universitas Tarumanagara, Jakarta \\ Email: joe.717172010@stu.untar.ac.id \\ ${ }^{2}$ Fakultas Psikologi, Universitas Tarumanagara, Jakarta \\ Email: samsunuwijatim@fpsi.untar.ac.id \\ ${ }^{3}$ Fakultas Psikologi, Universitas Tarumanagara, Jakarta \\ Email: sri.tiatri@untar.ac.id
}

Masuk: 21-03-2020, revisi: 28-04-2020, diterima untuk diterbitkan: 30-04-2020

\begin{abstract}
Limited reading and writing abilities in children with dyslexia make it difficult for them to succeed academically when given a typical learning method. In addition to difficulties in the academic field, children with dyslexia also experience difficulties in their psychosocial functioning. Emotional problems become "secondary handicaps" which often occur in children with dyslexia and will cause psychological disorders if not treated early. Children who show indications of dyslexia need to be given appropriate emotional guidance to obtain the emotional competence needed to enable them to express emotions in a healthy manner. Interventions in the form of expressive art therapy were given to six participants; children aged 8 to 9 years who were diagnosed with dyslexia. Each participant has received six art therapy sessions and completed the Emotion Expression Scale for Children (EESC) measuring instrument as the pretest and posttest. The purpose of this study is to explore factors that influenced the effectiveness of expressive art therapy results on emotional expression in children with dyslexia. This paper will focus on analyzing the interview results from six participants and their main caregiver. Data collection was carried out qualitatively through individual interviews. The results of the qualitative thematic analysis showed that increasing EESC scores on participants can be explained by two main factors. First, emotion coaching received from the environment. Second, the social judgement perceived by the participants. Differences in comorbidities, cultures, and conditions of participants during interventions might influence the results of this study.
\end{abstract}

Keywords: dyslexia, emotion expression factors, expressive art therapy, emotion expression

\begin{abstract}
ABSTRAK
Keterbatasan kemampuan membaca dan menulis pada anak dengan disleksia membuat mereka sulit untuk berhasil secara akademis ketika diberikan metode belajar yang tipikal. Selain kesulitan di bidang akademik, anak-anak dengan disleksia juga mengalami kesulitan dalam fungsi psikososial mereka. Permasalahan emosional menjadi "secondary handicap" yang seringkali muncul pada anak dengan disleksia dan akan menyebabkan gangguan psikologis jika tidak ditangani sejak dini. Anak disleksia perlu diberikan bimbingan emosional yang tepat untuk memperoleh kompetensi emosional yang diperlukan agar mereka mampu mengekspresikan emosi dengan cara yang sehat. Dalam riset ini, intervensi berupa terapi seni ekspresif telah diberikan terhadap enam partisipan, yaitu anak berusia 8 hingga 9 tahun yang terdiagnosis disleksia. Setiap partisipan telah melakukan enam sesi terapi seni dan menyelesaikan alat ukur Emotion Expression Scale for Children (EESC) sebagai pretest, juga posttest. Tujuan dari penelitian ini adalah untuk mengeksplorasi faktor yang memengaruhi efektivitas terapi seni ekspresif terhadap ekspresi emosi pada anak dengan disleksia. Penelitian ini akan berfokus menganalisis hasil wawancara dengan keenam partisipan dan pengasuh utama mereka. Pengambilan data dilakukan secara kualitatif melalui metode wawancara individual. Hasil analisis tematik kualitatif menunjukkan bahwa peningkatan skor EESC pada partisipan dapat dipengaruhi oleh dua faktor utama. Pertama, pengajaran emosi yang diterima dari lingkungan. Kedua, penilaian lingkungan sosial yang dipersepsikan oleh partisipan. Perbedaan dalam komorbiditas, budaya, dan kondisi partisipan selama intervensi juga dapat menjadi faktor yang memengaruhi hasil penelitian ini.
\end{abstract}

Kata Kunci: disleksia, faktor ekspresi emosi, terapi seni ekspresif, emosi anak

\section{PENDAHULUAN}

\section{Latar Belakang}

Disleksia merupakan bentuk kesulitan belajar spesifik yang paling sering ditemukan, yaitu sebanyak 80\% dari keseluruhan gangguan belajar lainnya (International Dyslexia Association 
dalam Kementerian Pemberdayaan Perempuan dan Perlindungan Anak Republik Indonesia, 2016; Cortiella \& Horowitz, 2014). Prevalensi disleksia di Indonesia belum diketahui, namun prevalensi disleksia di beberapa negara seperti Amerika Serikat dan Inggris berkisar antara 517\% dan angka tersebut tergolong tinggi (International Dyslexia Association, 2017). Disleksia sendiri merupakan disabilitas belajar spesifik yang ditandai oleh kesulitan dalam mengenali kata secara akurat dan/atau fasih, serta kemampuan mengeja dan decoding yang buruk (International Dyslexia Association, 2017). Individu dengan disleksia akan kesulitan untuk berhasil secara akademis jika dibiarkan dalam lingkungan belajar yang tipikal, yaitu belajar melalui membaca dan menulis dengan huruf maupun angka (International Dyslexia Association, 2017).

Kesulitan dalam bidang akademis hanya salah satu dari berbagai permasalahan yang dialami oleh anak yang mengalami disleksia. Anak dengan disleksia juga mengalami kesulitan dalam mengidentifikasi, meregulasi, dan mengekspresikan emosi dengan cara yang sesuai dengan norma sosial (Zysberg \& Kassler, 2017). Meskipun ingin mengekspresikan emosi secara verbal seperti anak pada umumnya, mengakses kosakata, nama, dan susunan cerita yang tepat merupakan tugas yang lebih sulit bagi anak dengan disleksia (International Dyslexia Association, 2014; International Dyslexia Association, 2017).

Memasuki Sekolah Dasar (SD), anak mulai dituntut untuk memiliki kemampuan yang relatif sama dengan teman-temannya, baik secara akademis maupun sosial. Tuntutan akan terasa lebih berat pada anak dengan disleksia sebab selain kesulitan menyesuaikan diri dengan materi pelajaran, anak juga perlu menyesuaikan diri secara sosial. Kesulitan mengekspresikan emosi menjadi salah satu aspek yang menantang proses adaptasi sosial anak di lingkungan sekolah (Rydell, Berlin, \& Bohlin, 2003). Kesulitan emosional pada anak menjadi "secondary handicap", yaitu gangguan sekunder yang muncul akibat trauma dari gangguan utama yang dialami (Sinason dalam Case \& Dalley, 2008). Pada anak dengan disleksia, kesulitan emosional dapat menjadi permasalahan yang akan terbawa hingga jenjang pendidikan selanjutnya jika tidak ditangani sejak dini (Case \& Dalley, 2008; Kavale \& Mostert, 2004).

Permasalahan emosi lain yang dialami oleh anak dengan disleksia adalah kecenderungan untuk menutupi perasaan negatif yang dialaminya. Hal ini dibuktikan melalui penelitian oleh Singer (2008) pada 60 anak dengan disleksia berusia 9-12 tahun yang mendapatkan evaluasi negatif secara akademis. Hasil menunjukkan bahwa 59\% anak memilih untuk berpura-pura seolah tidak ada hal serius yang terjadi. Mereka berusaha menutupi perasaan marah, sedih, bingung, malu, bersalah, atau perasaan bodoh. Delapan puluh dua persen dari 60 anak-anak tersebut memilih untuk melakukan justifikasi kognitif agar mereka merasa lebih baik, dibanding mengekspresikan emosi mereka.

Emosi yang secara terus menerus tidak disalurkan, dapat mengganggu fungsi sosial individu. Individu yang menghambat, membatasi, atau bahkan tidak mengekspresikan emosi mereka akan rentan mengembangkan fungsi sosial yang maladaptif (Krystal \& Krystal, 1988; Thompson, 1994; Gross \& Levenson, 1997). Risiko menjadi semakin tinggi pada anak dengan disleksia yang berada di Indonesia. Budaya Indonesia yang dipengaruhi budaya Timur mendorong individu untuk menyimpan, bahkan menekan (suppress) emosi mereka (Butler, Lee, \& Gross, 2007). Anak yang memenuhi kriteria diagnosis disleksia, perlu untuk mendapatkan intervensi sedini mungkin (Reid, 2007). Dengan demikian, anak dengan disleksia perlu diberikan bimbingan emosional yang tepat untuk memperoleh kompetensi emosional yang diperlukan agar mereka mampu mengekspresikan emosi dengan cara yang sehat. 


\section{Ekspresi Emosi}

Ekspresi emosi mengacu pada cara seseorang menyampaikan pengalaman emosional melalui perilaku verbal dan nonverbal (Gross, 1998, 1999). Dalam perkembangan konsep ekspresi emosi, dua peneliti topik regulasi emosi; Penza-Clyve dan Zeman (2002), merumuskan aspekaspek yang akan mewakili konsep ekspresi emosi. Pertama, kesadaran emosi (emotion awareness) sebagai kemampuan individu untuk memberi label pada pengalaman emosional mereka. Aspek kedua adalah motivasi untuk mengekspresikan emosi yang mencakup keinginan untuk berkomunikasi atau mengekspresikan emosi kepada orang lain, terlepas dari kemampuan untuk melakukannya.

Kesulitan anak dengan disleksia dalam mengekspresikan emosi secara verbal atau kesulitan mengerti maksud perkataan orang lain seringkali membawa dampak serius pada anak. Saat anak mencoba menjalin relasi dengan teman sebayanya, anak akan dinilai tidak kompeten dan tidak efektif dalam berinteraksi sosial (International Dyslexia Association, 2017; Kavale \& Mostert, 2004). Anak akan mengalami penolakan oleh teman-temannya (Wiener, 2004). Anak-anak yang mengalami penolakan oleh teman sebaya berisiko mengalami gangguan mental dan perilaku di masa kanak-kanak dan dewasa (Bagwell, Newcomb, \& Bukowski, 1998). Semakin lama anak mengolah emosi dengan cara yang maladaptif, maka mereka akan semakin rentan mengembangkan pola-pola psikopatologis. Ketika anak-anak mampu mengekspresikan emosi dengan lebih baik, perkembangan emosi anak akan semakin optimal dan risiko anak mengalami "secondary handicap" akan terminimalisir.

Penelitian ini merupakan penelitian lanjutan yang akan mengeksplorasi hasil penelitian terdahulu (Irene, 2019) mengenai efek terapi seni ekspresif terhadap ekspresi emosi anak dengan disleksia. Pada penelitian sebelumnya, intervensi terapi seni ekspresif telah dilakukan terhadap enam anak disleksia. Keenam partisipan mengikuti pretest dengan mengisi kuesioner Emotion Expression Scale for Children (EESC) dan wawancara individual ekspresi emosi. Setelah itu, partisipan menjalankan enam sesi terapi seni ekspresif. Terapi seni ekspresif dirancang dengan mengacu pada tahapan seni ekspresif menurut Ganim (1999). Secara operasional, terapi seni ekspresif pada penelitian Irene (2019) merupakan proses mengekspresikan emosi dan ide di atas sebuah kertas berukuran A3, dalam bentuk gambar atau warna secara spontan. Partisipan dapat memilih satu atau lebih alat mewarnai yang disediakan, antara lain; pensil warna, spidol, krayon, cat air, dan cat poster. Setelah pembuatan hasil karya, peneliti melakukan probing lebih lanjut mengenai hasil karya yang dihasilkan. Setelah menyelesaikan keenam sesi, partisipan kembali mengisi kuesioner EESC dan mengikuti wawancara individual sebagai posttest intervensi.

Hasil riset Irene (2019) yang menggunakan terapi seni ekspresif untuk meningkatkan ekspresi emosi partisipan, menunjukkan bahwa secara kuantitatif, terdapat peningkatan skor ekspresi emosi pada empat partisipan sebelum dan sesudah menjalani terapi. Dua partisipan juga mampu menyebutkan lebih banyak kosakata emosi pada wawancara posttest. Secara kualitatif, terlihat peningkatan ekspresivitas pada gambar empat orang partisipan melalui peningkatan jumlah tema, ukuran, warna, dan kualitas garis. Penelitian ini akan menganalisa secara kualitatif faktor-faktor yang memengaruhi perubahan tersebut.

Pada penelitian McNulty (2003) ditemukan bahwa pengalaman setiap orang dengan disleksia beragam satu dengan lainnya. Perbedaan pengalaman dapat dipengaruhi oleh kepribadian, sosioekonomi, budaya dalam keluarga, dan deteksi dini. Penelitian ini akan menganalisis hasil wawancara pretest dan posttest keenam partisipan dalam rangka mengidentifikasi faktor-faktor yang memengaruhi perubahan ekspresi emosi partisipan. Dengan mengetahui faktor-faktor yang 
mempengaruhi ekspresi emosi anak dengan disleksia, maka pemberian intervensi oleh pengasuh maupun ahli, akan lebih optimal. Hasil dari penelitian ini juga diharapkan dapat menjadi sumbangsih literatur bagi perkembangan emosi anak dengan kesulitan belajar spesifik, terutama disleksia.

\section{METODE PENELITIAN}

\section{Partisipan}

Partisipan yang memenuhi syarat untuk penelitian ini memenuhi kriteria berikut: Partisipan (1) berusia antara 8 hingga 12 tahun dan memenuhi gejala disleksia; (2) sedang menempuh pendidikan di sekolah formal yang berpedoman pada Kurikulum Nasional; (3) tidak memiliki disabilitas intelektual; (4) menyetujui untuk menghadiri enam sesi terapi; dan (5) dalam kondisi fisik yang sehat.

Pemilihan sampel dilakukan secara non-probabilitas menggunakan purposive sampling melalui komunitas orang tua dengan anak dengan disleksia, konselor sekolah di wilayah Jabodetabek, dan penyebaran informasi mengenai rekrutmen partisipan penelitian melalui media sosial. Orang tua dari anak yang memenuhi kriteria partisipan dan menunjukkan minat untuk berpartisipasi, dihubungi secara individual oleh peneliti. Peneliti kemudian meminta surat keterangan dokter atau psikolog sebagai bukti pendukung bahwa gejala disleksia terpenuhi. Partisipan dan orang tua partisipan diberikan informasi secara tertulis dan lisan mengenai proses pengambilan data yang akan dilakukan. Proses intervensi dimulai setelah persetujuan diperoleh dari orang tua partisipan maupun partisipan itu sendiri.

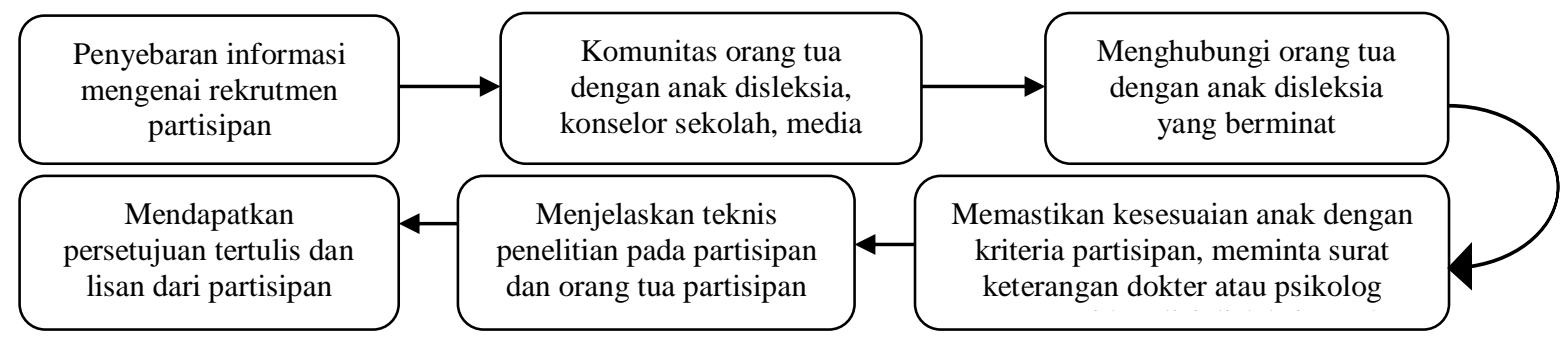

Gambar 1. Skema Rekrutmen Partisipan Penelitian

\section{Desain penelitian}

Data penelitian diperoleh dengan menggunakan metode kualitatif. Metode kualitatif yang digunakan adalah wawancara individual dengan masing-masing partisipan dan pengasuh utama mereka. Wawancara dengan partisipan dilakukan sebelum intervensi, selama intervensi, dan di akhir proses intervensi. Wawancara terhadap partisipan dilakukan di rumah partisipan dan laboratorium konseling Universitas Tarumanagara. Setting wawancara telah dipastikan kondusif, yaitu di ruang yang minim distraksi. Wawancara dengan pengasuh utama dilakukan melalui telepon, tiga minggu setelah intervensi berakhir.

Penelitian ini berjenis deskriptif eksploratif karena penelitian ini bertujuan untuk mengumpulkan informasi dan menggambarkan suatu gejala atau variabel (Arikunto, 2006), yaitu faktor yang memengaruhi perubahan skor ekspresi emosi anak dengan disleksia. Data kualitatif hasil wawancara individual dengan keenam partisipan dan pengasuh utama mereka dianalisis secara tematik. Analisis tematik kualitatif merupakan metode identifikasi, analisis, dan pelaporan pola atau tema dalam data (Braun \& Clarke, 2006). Hasil analisis yang diperoleh diharapkan dapat 
menjadi dasar penelitian lebih lanjut atau untuk merancang intervensi yang lebih efektif bagi anak dengan disleksia.

\section{Instrumen penelitian}

Instrumen pengumpulan data kualitatif yang digunakan dalam penelitian ini adalah panduan wawancara semi terstruktur yang dikembangkan oleh peneliti. Panduan wawancara bagi partisipan berisi 10 pertanyaan berjenis open-ended. Daftar pertanyaan beserta probing disusun berdasarkan dua aspek ekspresi emosi menurut Penza-Clyve dan Zeman (2002). Pada aspek pertama, kesadaran emosi, terdapat tiga indikator yang diukur, yaitu: (1) Kemampuan regulasi emosi; (2) Cara coping emosi; dan (3) Internalisasi distress psikologis. Contoh pertanyaan yang ditanyakan pada aspek kesadaran emosi adalah, "Perasaan apa saja yang pernah kamu rasakan?", "Apa yang kamu lakukan saat merasa marah?", dan "Dengan cara apa kamu mengeluarkan perasaan sedih?". Aspek kedua, motivasi mengekspresikan emosi, terdiri dari empat indikator: (1) Inhibisi kesedihan dan kemarahan; (2) Kontrol perasaan dalam konteks pertemanan; (3) Gejala internalisasi emosi; dan (4) Penilaian teman terhadap perilaku menarik diri. Contoh pertanyaan pada aspek motivasi mengekspresikan adalah, "Mengapa kamu merasa perlu untuk mengatakan hal yang kita rasakan?", "Apa yang kamu lakukan saat merasa sedih di depan teman-teman?", dan “Apa yang terjadi jika kamu menceritakan perasaanmu pada orang lain?". Pertanyaan yang ditanyakan pada orang tua partisipan adalah dua buah pertanyaan open-ended: (1) Apa saja perubahan yang terjadi pada ekspresi emosi anak Anda setelah mengikuti terapi seni ekspresif? (2) Menurut Anda, apa saja yang memengaruhi ada atau tidaknya perubahan ekspresi emosi anak setelah terapi?

Hasil kuantitatif yang ditampilkan pada penelitian ini merupakan skor pretest dan posttest terapi seni ekspresif. Skor diperoleh melalui instrumen Emotion Expression Scale for Children (EESC), sebuah kuesioner self-report yang mengukur kemampuan ekspresi emosi anak usia 9-12 tahun. Alat ukur dengan 16 butir pernyataan tersebut disusun oleh Penza-Clyve dan Zeman (2002) dan diadaptasi ke dalam Bahasa Indonesia dalam penelitian Irene (2019), sehingga menjadi 12 butir pernyataan setelah melalui uji coba.

\section{HASIL DAN PEMBAHASAN}

\section{Gambaran partisipan}

Melalui proses rekrutmen partisipan, terdapat enam orang partisipan yang bersedia mengikuti rangkaian pengambilan data penelitian ini. Keenam orang tersebut juga memenuhi kriteria partisipan, yaitu berusia 8-12 tahun dan memenuhi ciri disleksia, dengan disertai surat keterangan dokter atau psikolog. Informasi deskriptif mengenai demografi partisipan dapat dilihat pada Tabel 1.

Tabel 1. Data Demografis Partisipan

\begin{tabular}{cccc}
\hline Inisial & $\begin{array}{c}\text { Jenis } \\
\text { Kelamin }\end{array}$ & Usia & Suku Bangsa \\
\hline A & Perempuan & 9 tahun 4 bulan & Batak \\
\hline F & Laki-laki & 9 tahun 6 bulan & Sunda-Jawa \\
\hline I & Perempuan & 9 tahun 10 bulan & Tionghoa \\
\hline $\mathbf{M}$ & Perempuan & 9 tahun 11 bulan & Tionghoa \\
\hline $\mathbf{R}$ & Laki-laki & 9 tahun 9 bulan & Tionghoa \\
\hline $\mathbf{S}$ & Perempuan & 8 tahun 7 bulan & Aceh-Batak \\
\hline
\end{tabular}


Mayoritas partisipan berusia 9 tahun, dengan rata-rata usia 9,5 tahun. Empat dari enam partisipan berjenis kelamin perempuan. Partisipan telah memiliki surat keterangan dari dokter atau psikolog mengenai kondisi disleksia yang dimiliki. Tingkat keparahan disleksia yang dimiliki masingmasing partisipan belum dapat diidentifikasi, karena surat keterangan dari dokter maupun psikolog tidak menyertakan informasi tersebut. Karakteristik lain yang serupa dari keenam partisipan adalah seluruhnya memiliki ibu sebagai pengasuh utama. Seluruh partisipan juga bersekolah di SD Swasta di Jakarta.

\section{Hasil intervensi}

Hasil intervensi pada penelitian sebelumnya menunjukkan bahwa empat dari enam partisipan mengalami peningkatan skor EESC setelah pemberian intervensi terapi seni. Empat partisipan menunjukkan peningkatan ekspresi emosi secara kualitatif, satu partisipan menunjukkan penurunan tingkat ekspresivitas emosi negatif setelah intervensi, dan satu partisipan menemukan cara coping emosi yang dirasa cocok baginya. Peneliti kemudian menganalisis hasil wawancara bersama enam partisipan selama proses intervensi, serta hasil wawancara follow-up bersama empat orang tua partisipan. Faktor-faktor yang memengaruhi ekspresi emosi anak akan dideskripsikan berdasarkan dua aspek ekspresi emosi, yaitu kesadaran emosi (emotion awareness) dan motivasi mengekspresikan emosi.

Analisis tematik dalam penelitian ini dilakukan secara induktif atau "bottom up" (Braun \& Clarke, 2006). Pertama-tama, peneliti melakukan transkrip hasil rekaman wawancara. Kedua, peneliti membaca kembali hasil transkrip keseluruhan dan mencatat ide-ide pokok yang ditemukan seputar ekspresi emosi. Ketiga, peneliti memberi kode pada percakapan seputar faktor mengekspresikan emosi. Keempat, peneliti mengumpulkan penggalan percakapan yang memiliki kode serupa ke dalam kelompok besar (tema). Kelima, peneliti menganalisis masing-masing tema, kemudian memisahkan hasil analisis ke dalam dua aspek ekspresi emosi. Peneliti juga menganalisis hubungan hasil penelitian ini dengan hasil penelitian terdahulu. Berikut merupakan faktor-faktor yang memengaruhi ekspresi emosi anak disleksia dalam penelitian Irene (2019).

\section{Faktor yang memengaruhi kesadaran emosi}

Empat partisipan menunjukkan peningkatan kesadaran emosi secara kualitatif dan disertai dengan peningkatan skor EESC pada aspek kesadaran. Peneliti kemudian mengeksplorasi faktor yang memengaruhi peningkatan kesadaran emosi tersebut.

Pada anak-anak dengan skor kesadaran emosi yang mengalami peningkatan, ditemukan bahwa sebelum intervensi, partisipan tidak memahami jenis-jenis emosi karena tidak terbayang oleh mereka. Setelah menuangkan emosi ke dalam bentuk, gambar, atau warna, partisipan mulai mengidentifikasi "wujud" emosi mereka. Hal ini sejalan dengan tahap perkembangan kognitif Piaget. Anak usia 8 hingga 9 tahun memroses informasi secara konkrit operasional (McDevitt \& Ormrod, 2010). Menuangkan emosi sebagai sebuah konsep yang abstrak, ke dalam wujud konkrit berupa karya seni, dapat membantu anak dalam mencapai pembelajaran mengenai emosi. Hal ini terlihat pada partisipan S, A, dan M.

Pada awal sesi, S mengatakan bahwa ia tidak pernah merasa marah dan sedih. Meskipun demikian, S mampu menyebutkan kesukaan dan ketidaksukaannya terhadap kondisi tertentu. Misalnya saat temannya menjahilinya, S mengatakan bahwa ia tidak suka sehingga ia melapor pada gurunya. $\mathrm{S}$ belum mampu memberi label pada perasaannya. Setelah $\mathrm{S}$ menggambarkan situasi yang ia sukai dan tidak, $\mathrm{S}$ menyadari bahwa perasaan-perasaan tersebut dapat diberi nama. Selama sesi intervensi berjalan, partisipan A menyadari bahwa marah merupakan emosi 
berwarna merah yang membuatnya merasa panas, ingin berteriak, dan melotot. A juga belajar bahwa marah merupakan emosi yang wajar dirasakan manusia, asalkan tidak disertai dengan perbuatan buruk. Selama proses intervensi, partisipan M mengeksplorasi berbagai warna yang mewakili perasaannya. Pada saat wawancara mengenai karya seni yang dihasilkan, M mengatakan bahwa ia terkejut karena perasaannya dapat dituangkan dalam warna dan memiliki bentuk.

Identifikasi emosi yang lebih lamban dan kurang efektif merupakan kecenderungan yang ditemukan pada anak-anak dengan kesulitan belajar spesifik (Elias dalam Zysberg \& Kasler, 2017). Meskipun demikian, orang tua juga berkontribusi dalam pendidikan emosi anak (emotion coaching; Gottman, Katz, \& Hooven, 1996). Anak akan mampu mengidentifikasi dan memberi label pada emosi jika diajarkan sejak dini. Faktor keterlibatan orang tua dalam memberikan pendidikan emosi menjadi berpengaruh, terutama pada anak dengan disleksia yang seringkali kesulitan mempelajari bahasa verbal.

Faktor lain yang dapat memengaruhi ekspresi emosi adalah menemukan media ekspresi yang sesuai dengan minat dan karakteristik anak. Anak dengan disleksia menunjukkan kesulitan untuk mengungkapkan emosi secara verbal di lingkungan pergaulan, sehingga memiliki kecenderungan untuk menyimpan emosinya. Partisipan $\mathrm{R}$ telah menunjukkan kesadaran emosi yang tinggi secara kuantitatif sebelum pemberian terapi seni ekspresif pada penelitian sebelumnya. $\mathrm{R}$ sudah mampu mengidentifikasi emosi yang ia rasakan, tetapi belum memahami cara menyalurkannya secara tepat. Wawancara follow-up dengan ibu dari $\mathrm{R}$ menunjukkan bahwa $\mathrm{R}$ mendapatkan insight mengenai hal yang harus dilakukan saat merasakan emosi negatif. $\mathrm{R}$ menemukan bahwa membuat karya seni seperti menggambar merupakan aktivitas penyaluran emosi yang cocok untuknya. "Kita jadi tahu, e... Kalo kemaren dia bilang, 'Kalo aku marah tuh, aku lebih suka coret-coret kertas.' Nah, itu kita tahu dari terapi kemaren." [Ibu dari R]

\section{Faktor yang memengaruhi motivasi mengekspresikan emosi}

Hasil kuantitatif dan kualitatif intervensi menunjukkan bahwa keenam partisipan tidak mengalami perubahan yang signifikan dalam motivasi mengekspresikan emosi. Beberapa partisipan seperti I, R, dan M mengatakan bahwa emosi negatif seperti sedih dan marah tidak perlu untuk ditunjukkan karena akan membuat mereka merasa malu. Berbeda dengan emosi negatif, emosi positif seperti senang dan gembira boleh diketahui orang lain. Jawaban ketiga partisipan tidak berubah baik di awal maupun akhir intervensi.

Faktor yang membuat ketiga partisipan enggan mengekspresikan emosi negatif adalah karena tidak ingin dinilai negatif oleh lingkungan. Partisipan I, R, dan M mengatakan bahwa emosi negatif tidak boleh diketahui oleh orang lain selain ibu mereka. Contohnya adalah saat sedih, partisipan $\mathrm{R}$ akan sebisa mungkin tidak menitikkan air mata meskipun ingin menangis. Bahkan $\mathrm{R}$ merasa seperti ingin melakukan handstand agar air matanya tidak jadi mengalir keluar. $\mathrm{R}$ merasa bahwa saat ia mengekspresikan rasa sedih atau marah, teman-temannya sering mengejek atau menertawakan R. Ejekan dari teman $\mathrm{R}$ dianggap sebagai penolakan, sehingga $\mathrm{R}$ memilih untuk memendam emosi negatifnya sendiri. $\mathrm{R}$ merasa lebih baik untuk bercerita pada ibunya mengenai hal yang ia rasakan.

Hal ini sejalan dengan hasil penelitian Garber dalam Chaplin (2015) yang menemukan bahwa anak-anak memilih untuk mengekspresikan emosi negatif (termasuk kesedihan dan kemarahan) di depan orang tua mereka atau saat sendirian daripada ketika bersama teman sebaya. Mereka berekspektasi bahwa orang tua akan menerima ekspresi emosi mereka, sedangkan teman akan 
menolak. Emosi negatif yang dihasilkan dari penolakan oleh teman, diperburuk oleh kesulitan R dalam mengekspresikan emosi melalui kata-kata. Sebagai anak dengan disleksia, R lebih nyaman mengekspresikan emosi secara nonverbal seperti melalui gambar atau gestur.

Berbeda dengan pertimbangan I, R, dan $M$ yang memilih untuk menyimpan emosi negatif mereka. Bagi partisipan S dan F, emosi apa pun perlu untuk diekspresikan. Partisipan S memilih untuk mengekspresikan emosinya karena akan membuatnya merasa lega. S pernah merasa kesal karena teman-temannya tidak memahami perasaannya, yaitu dengan menertawakan atau mengabaikan cerita $S$. Meskipun demikian, $S$ tetap merasa bahwa ia tidak salah karena ia hanya bercerita. Saat mengalami penolakan oleh temannya, $\mathrm{S}$ tetap mencoba untuk bercerita pada guru atau orang tuanya. Pada partisipan F, nilai moral menjadi pertimbangan dalam memutuskan untuk mengekspresikan emosi. Menurut F, menyimpan emosi sama dengan berbohong. Jika $\mathrm{F}$ tidak memberitahu perasaannya, artinya ia berbohong.

Melalui jawaban partisipan, dapat terlihat bahwa nilai budaya menjadi faktor yang menentukan cara pandang individu dalam menilai emosi. Budaya sendiri diturunkan antar generasi, meskipun tidak selalu adaptif (Turiel, 2012; Feist \& Feist, 2013). Budaya memengaruhi display rules seseorang, namun lebih luas lagi, budaya juga memengaruhi cara pandang moral individu (Matsumoto, Seung Hee Yoo, \& Fontaine, 2008; Turiel, 2012). Penilaian moral sendiri berkaitan erat dengan emosi anak (Turiel, 2012). Seperti partisipan F, anak-anak akan mengekspresikan emosi sesuai dengan penalaran moral yang mereka miliki.

Pada partisipan A, ditemukan emosi tertentu yang enggan diekspresikannya, yaitu marah dan takut. A percaya bahwa emosi memiliki kaitan erat dengan keyakinan yang dianutnya. A menolak saat harus membayangkan atau menuangkan ekspresi marah ke dalam karya seni. A mengatakan bahwa ia tidak pernah marah dan tidak ingin marah karena marah adalah perasaan yang membuatnya merasa buruk. Sebanyak tiga kali, A mengatakan bahwa Tuhan mengatakan bahwa orang yang marah akan menjadi tua, kemudian mati. Selain marah, A juga enggan mengekspresikan emosi takut. A merasa bahwa ia tidak pernah merasakannya karena Tuhan selalu menyertainya. A berkata bahwa monster dapat membuatnya takut, namun A merasa bahwa Tuhan lebih besar dari monster yang membuatnya takut. Melalui jawaban A, terlihat bahwa A memiliki kesadaran akan emosi marah dan takut, namun kepercayaan menjadi faktor yang mempengaruhi ekspresi dari emosi-emosi tersebut.

Beberapa emosi memiliki faktor lain yang memengaruhi ekspresivitasnya. Faktor yang dapat memengaruhi ekspresi emosi marah dapat berupa tingkat agresivitas anak (Ramsden \& Hubbard, 2002). Meskipun belum terdapat nilai agresivitas secara kuantitatif, partisipan F menunjukkan agresivitas yang tinggi melalui tema-tema agresivitas yang muncul dalam gambarnya. Selain itu, partisipan $\mathrm{F}$ juga mengatakan bahwa emosi marah yang ia rasakan sudah seharusnya ditunjukkan.

Penelitian selanjutnya dapat mengkaji pengaruh ekspresivitas emosi dalam keluarga, kelekatan dengan orang tua, serta pengajaran emosi (emotion coaching) oleh orang tua maupun guru (Ramsden \& Hubbard, 2002). Hal ini dikarenakan perkembangan kompetensi sosial anak tidak hanya dipengaruhi oleh lingkungan yang responsif, tetapi arahan langsung dari orang tua mengenai ekspresi dan pengalaman emosi juga penting (Gottman, Katz, and Hooven, 1996). 
Penelitian ini melibatkan sejumlah kecil sampel dan tidak signifikan secara statistik, oleh karena itu, diperlukan interpretasi yang cermat. Selain itu, partisipan yang berkontribusi pada penelitian ini tidak memiliki status diagnostik yang sama, sehingga mungkin mempengaruhi reliabilitas hasil. Diperlukan studi lebih lanjut dengan ukuran sampel yang lebih besar.

\section{KESIMPULAN DAN SARAN}

Melalui wawancara dengan partisipan dan caregiver partisipan, dapat disimpulkan beberapa faktor yang memengaruhi ekspresi emosi anak dengan disleksia. Pertama, anak perlu mengenal emosi dalam bentuk yang konkrit, menyesuaikan dengan tahap perkembangan kognitif mereka. Kedua, keterlibatan orang tua dalam memberikan pengajaran emosi untuk menyadari hal yang dirasakan, serta memberi label pada perasaan tersebut. Ketiga, ekspresi emosi memerlukan media ekspresi yang sesuai bagi anak. Jika anak merasa tidak nyaman mengungkapkan emosi melalui komunikasi verbal, maka perlu untuk diberikan media nonverbal sebagai sarana penyaluran emosi. Keempat, penilaian sosial menjadi faktor yang dipertimbangkan anak dalam mengekspresikan emosi mereka. Jika lingkungan pertemanan anak memberikan penolakan terhadap ekspresi emosi yang ditampilkan, maka anak akan cenderung memendam emosinya. Kelima, nilai budaya dan kepercayaan yang anak pelajari dari lingkungannya akan memengaruhi tampilan emosi-emosi tertentu. Selain itu, tingkat agresivitas anak juga dapat memengaruhi ekspresi emosi anak.

Beberapa saran praktis yang dapat diberikan terkait penemuan dalam penelitian ini adalah:

1. Perlu institusi pendidikan yang mampu mengakomodasi perkembangan aspek emosi dan sosial anak selain daripada aspek akademis. Jika kesulitan akademis dan sosioemosi anak terakomodasi, maka jarak antara potensi dan performa akademis akan semakin kecil. Anak akan lebih rentan mengalami frustrasi dan underachievement jika tetap dibiarkan dalam institusi pendidikan yang tidak mampu mengakomodasi kebutuhan anak dengan disleksia.

2. Intervensi dalam aspek akademis seperti terapi remedial tetap perlu untuk diberikan pada anak. Interaksi intervensi akademis dan sosioemosi akan lebih efektif dalam membantu anak beradaptasi. Intervensi juga perlu untuk dilakukan sedini mungkin, dan didampingi oleh dukungan untuk mengeksplorasi bakat dan minat di berbagai bidang, serta dukungan keluarga.

3. Kesulitan anak dengan disleksia dalam mengekspresikan emosi secara verbal perlu untuk dibimbing. Meskipun seni dapat menjadi sebuah media ekspresi emosi yang sesuai bagi anak, anak tetap perlu untuk melakukan ekspresi emosi verbal untuk beradaptasi dengan lingkungan sosialnya. Anak dapat diajak untuk bermain peran (roleplay) seolah mereka merasakan emosi tertentu, kemudian mengungkapkannya pada orang lain.

4. Aktivitas membuat karya seni dapat dilanjutkan oleh orang tua secara mandiri, karena keterlibatan orang tua dalam pendidikan emosi merupakan faktor penting bagi anak dalam mengekspresikan emosi. Orang tua dapat menyertakan dialog mengenai emosi yang ditampilkan dalam karya seni, dan juga mengajarkan kosakata-kosakata emosi yang membantu anak mengekspresikannya secara verbal. Terlebih, orang tua juga dapat mengarahkan agar tampilan emosi anak tetap sesuai dengan nilai dan norma yang berlaku di keluarga maupun masyarakat.

\section{Ucapan Terima Kasih (Acknowledgement)}

Peneliti mengucapkan terima kasih kepada seluruh partisipan penelitian ini, serta orang tua partisipan yang telah memberi izin pengambilan data. Terima kasih kepada DPSG Indonesia yang telah menyalurkan informasi mengenai penelitian ini, serta Lembaga Pendidikan X yang telah memfasilitasi penyebaran informasi dan pengambilan data. 


\section{REFERENSI}

Arikunto, S. (2006). Prosedur penelitian: Suatu pendekatan praktek. Jakarta: Rineka Cipta.

Bagwell, C. L., Newcomb, A. F., \& Bukowski, W. M. (1998). Preadolescent friendship and peer rejection as predictors of adult adjustment. Child Development, 69, 140-153.

Braun, V., \& Clarke, V. (2006). Using thematic analysis in psychology. Qualitative Research in Psychology, 3(2), 77-101. doi: 10.1191/1478088706qp063oa

Butler, E. A., Lee, T. L., \& Gross, J. J. (2007). Emotion regulation and culture: Are the social consequences of emotion suppression culture-specific?. Emotion, 7(1), 30-38.

Case, C., \& Dalley, T. (Eds.). (2008). Art therapy with children: From infancy to adolescence. Routledge.

Chaplin T. M. (2015). Gender and emotion expression: A developmental contextual perspective. Emotion review: Journal of the International Society for Research on Emotion, 7(1), 1421. doi:10.1177/1754073914544408

Cortiella, C., \& Horowitz, S. H. (2014). The state of learning disabilities: Facts, trends and emerging issues. New York: National center for learning disabilities, 25, 2-45.

Feist, J., Feist, G. J., \& Roberts, T. (2013). Theories of personality (8 ${ }^{\text {th }}$ ed.). New York, NY: McGraw-Hill.

Ganim, B. (1999). Art and healing: Using expressive art to heal your body, mind, and spirit. New York, NY: Three Rivers Press.

Gottman, J. M., Katz, L. F., \& Hooven, C. (1996). Parental meta-emotion philosophy and the emotional life of families: Theoretical models and preliminary data. Journal of Family Psychology, 10, 243-268. doi:10.1037/0893-3200.10.3.243

Gross, J. J., \& Levenson, R. W. (1997). Hiding feelings: the acute effects of inhibiting negative and positive emotion. Journal of Abnormal Psychology, 106(1), 95.

Gross, J. J. (1998). The emerging field of emotion regulation: An integrative review. Review of General Psychology, Special Issue: New Ddirections in Research On Emotion, 2(3), 271-299.

Gross, J. J. (1999). Emotion regulation: Past, present, and future. Cognition \& Emotion, 13(5), $551-573$.

International Dyslexia Association (IDA). (2014). IDA Dyslexia handbook: What every family should know. [Online] Handbook. Retrieved from readingrockets.org/sites/default/files/IDA\%20Dyslexia\%20Handbook.pdf

International Dyslexia Association (IDA). (2017). Dyslexia in the classroom: What every teacher needs to know. [Online] Handbook. Retrieved from dyslexiaida.org/wpcontent/uploads/2015/01/DITC-Handbook.pdf

Irene, J. (2019). Pengaruh terapi seni ekspresif terhadap ekspresi emosi anak dengan indikasi disleksia (Unpublished manuscript). Universitas Tarumanagara, Jakarta.

Kavale, K. A., \& Mostert, M. P. (2004). Social skills interventions for individuals with learning disabilities. Learning Disability Quarterly, 27(1), 31-43.

Kementerian Pemberdayaan Perempuan dan Perlindungan Anak Republik Indonesia. (2016). Apa itu disleksia? Diakses melalui kemenpppa.go.id/index.php/page/read/41/729/apa-itudisleksia

Krystal, H., \& Krystal, J. H. (1988). Integration and self-healing: Affect, trauma, alexithymia. Hillsdale, NJ: Analytic Press.

Matsumoto, D., Hee, S., \& Fontaine, J. (2008). Mapping expressive differences around the world: The relationship between emotional display rules and individualism versus collectivism. Journal of Cross-Cultural Psychology, 39(1), 55-74. https://doi.org/10.1177/0022022107311854 
McDevitt, T. M., \& Ormrod, J. E. (2010). Child development and education (7th ed.). Upper Saddle River: Merrill.

McNulty, M. A. (2003). Dyslexia and the life course. Journal of Learning Disabilities, 36(4), 363-381. doi: http://dx.doi.org/10.1177/00222194030360040701

Penza-Clyve, S., \& Zeman, J. (2002). Initial validation of the Emotion Expression Scale for Children (EESC). Journal of Clinical Child \& Adolescent Psychology, 31(4), 540-547. doi:10.1207/s15374424jccp3104_12

Ramsden, S. R., \& Hubbard, J. A. (2002). Family expressiveness and parental emotion coaching: Their role in children's emotion regulation and aggression. Journal of Abnormal Child Psychology, 30(6), 657-667.

Reid, G. (2007). Dyslexia (Edisi ke-2). London: Continuum International Publishing Group.

Rydell, A. M., Berlin, L., \& Bohlin, G. (2003). Emotionality, emotion regulation, and adaptation among 5-to 8-year-old children. Emotion, 3(1), 30.

Singer, E. (2008). Coping with academic failure, a study of Dutch children with dyslexia. Dyslexia, 14(4), 314-333. doi:10.1002/dys.352

Scott, M. E., Scherman, A., \& Phillips, H. (1992). Helping individuals with dyslexia succeed in adulthood: Emerging keys for effective parenting, education, and development of positive self-image concept. Journal of Instructional Psychology, 19, 197-204.

Thompson, R. A. (1994). Emotion regulation: A theme in search of definition. Monographs of The Society For Research In Child Development, 59(2-3), 25-52.

Turiel, E. (2012). Moral reasoning, cultural practices and social inequalities. Innovación Educativa, 12(59), 17-32.

Wiener, J. (2004). Do peer relationships foster behavioral adjustment in children with learning disabilities? Learning Disability Quarterly, 27(1), 21-30.

Zysberg, L., \& Kasler, J. (2017). Learning disabilities and emotional intelligence. The Journal of Psychology, 151(5), 464-476. doi:10.1080/00223980.2017.1314929 